\title{
The charophytes of Israel: historical and contemporary species richness, distribution, and ecology
}

\author{
Roman E. Romanov ${ }^{1} \&$ Sophia S. Barinova ${ }^{2}$
}

${ }^{1}$ Central Siberian Botanical Garden of the Siberian Branch of the Russian Academy of Sciences, Zolotodolinskaja Str., 101, Novosibirsk, 630090, Russia, e-mail: romanov_r_e@ngs.ru

${ }^{2}$ Institute of Evolution, University of Haifa, Mount Carmel, Haifa, 31905, Israel

\begin{abstract}
The historical and contemporary species richness, distribution, and ecology of Israel charophytes are described. The first charophyte collection in this region was made in the $19^{\text {th }}$ century. Almost all reported localities were found earlier than 1970; some of them were not described. At the end of the $20^{\text {th }}$ century, only two localities of two species were reported. According to the literature, 13 species, including two undetermined species of Chara, and nearly 23 exact localities are known from Northern and Central Israel. We found seven species and one variety of charophytes in 23 new localities in eight river drainage basins from six ecological regions of Israel during the period extending from 2001-2011. One genus - Tolypella, and two species - Chara intermedia and Tolypella glomerata, were found for the first time in Israel. There are 15 species and four genera of charophytes known from the studied territory based on published and original data. The common habitats of charophytes in Israel are river channels, pools, and, especially, artificial water bodies. The Chara vulgaris var. longibracteata, C. gymnophylla and $C$. contraria are the most frequently encountered species. The species ecology is briefly characterized by selected environmental variables. It may be that charophytes are rather rare plants in Israel and that their distribution in space and time is strongly variable due to the absence of large water bodies in this region, great variability of natural environmental conditions and severe continuous transformations of the environment by human activity for millennia.
\end{abstract}

Key words: charophytes, Israel, species diversity, distribution, ecology

\section{Introduction}

The charophytes (Charales, Streptophyta), as macrophytes, may be very important components of vegetation in several types of water bodies. The thalli of these algae are among the largest in algae of continental water ecosystems. The very distinctive feature of charophyte thallus is its very regular morphology due to repeating of nearly identical segments.

Israel is partly situated in the eastern part of the Mediterranean region and partly within African-Eurasian Dry Zone (Perry \& Perry 1989). Its territory comprises several regions with diverse environmental features within its relatively small area. Based on this environmental diversity, we can assume a great diversity of algae of continental water bodies of Israel and, in particular, charophytes. Until now, the history of the study of Israel charophytes has not been described, and no generalization of all existing data has been attempted so far.
The aim of this work was to reveal historical and recent charophyte species richness, distribution, and ecology in continental water bodies of Israel.

\section{Study territory}

The territory of Israel includes three climatic zones: Mediterranean, semi-arid, and arid (Goldreich 2003). The main characteristic of the Israeli climate is a short rainy season from December to March. The altitude of this area varies between 400 meters below sea level in the Dead Sea depression to 1200 meters above sea level in the Golan Heights with a strong gradient of temperature, precipitation, and other climatic variables from north to south (Adler et al. 1985).

Israel's rivers are located mostly in the coastal plane and in the mountainous northern area. The only stream flowing in the Negev Desert, partly as a permanent stream, is the Zin stream. The area from the Golan Heights (about $33^{\circ} 11^{\prime} \mathrm{N}$ ) to Central Negev (about 
$30^{\circ} 50^{\prime} \mathrm{N}$ ) is transected by ten major streams and their tributaries. They are very small with a typical catchment area of a few hundred square kilometers and tens of kilometers in length. Nevertheless, until 1940s, most of the small rivers drew water throughout or for most of the year and supported diverse ecosystems of diverse fauna and flora. Since the establishment of the State of Israel in 1948, the country has undergone rapid urbanization and industrialization. As a result, and due to a low environmental awareness, the coastal rivers progressively have become the sinks of insufficiently treated wastewaters and solid wastes of diverse origins (BarOr 2000).

Based on this significant spatial environmental heterogeneity, a significant diversity in the characteristics of water bodies can be assumed. This diversity may support habitats for charophyte species with different ranges of environmental conditions. The four plant geographical territories on the territory of Israel, based on the vascular plants distribution (Galun 1970), also appears to corroborate this point of view (Fig. 1).

One of the significant ecological gradients in water bodies of Israel is the salinity of water, which correlated with aridity of the climate. Also, the environment of Israel was severely transformed due to human activity for millennia. On the one hand, this limits opportunity for the existence of charophytes and, on the other hand, the artificial water bodies created during this period may be suitable habitats for charophytes.

\section{Materials and methods}

During the period from 2001-2011, we collected 1,667 samples of algae from water bodies in 28 river drainage basins. We revealed microalgal species diversity in the collected samples but we paid special attention to charophytes because till now, no regular, extensive studies of this group of plants have been carried out in the Eastern Mediterranean.

Macroalgal samples were transported to the Institute of Evolution in a cool box and preserved partly in 3\% formaldehyde, partly herbarized and partly cultured. Cultivation was made in the greenhouse with 12/12 hours of darkness/light regime at $25^{\circ} \mathrm{C}$. The samples of oospores were taken from cultured samples after two weeks, if these were present. Algae were studied with dissecting Swift and Nikon microscopes under magnifications of X740-1850 and were photographed with the digital camera Inspector 1 and Leica 520 DC. Simultaneously, we measured conductivity, total dissolved solids content (TDS), and pH with HANNA HI 9813.

Charophyte species were studied and determined by living, fixed, and herbarium specimens, which were prepared after collection and stored at the Institute of Evolution. The collection of charophytes was made in

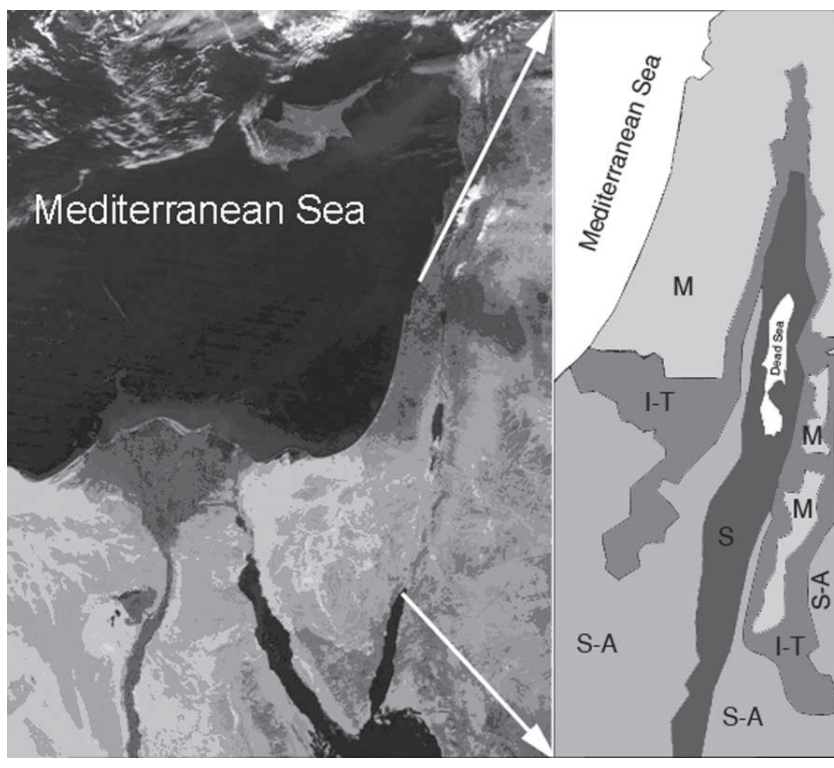

Fig. 1. Geographical location of Israel (www.earth.google.com) and plant geographical territories in the Eastern Mediterranean (after Galun 1970)

Explanations: M - Mediterranean; I-T - Irano-Turanian; S-A - Saharo-Arabian; S - Sudanian

different seasons and years in almost all localities. Numerous references were used for identification (Migula 1897; Groves \& Bullock-Webster 1924; Wood \& Imahori 1964, 1965; Hollerbach \& Krasavina 1983; Krause 1997; Schubert \& Blindow 2004; Cirujano et al. 2007). The studied material with serial numbers was stored at Haifa University and Central Siberian Botanical Garden of SB RAS (Novosibirsk).

\section{Results and Discussion}

\subsection{History of study}

The first charophyte collection was made in the $19^{\text {th }}$ century by N. Bové during his trip in the Palestine (Bové 1834). He found Chara in Berekhot Shelomo Solomon's ponds near Bethlehem, 23 July 1832. These three reservoirs were created in the antiquity as a water-supplying system for Jerusalem. According to these specimens, Alexander Braun described Chara fragilis var. meridionalis A. Braun 1834 (=C. meridionalis (A. Braun) Kütz.; Braun 1834, 1835; Decaisne 1834; Kützing 1849; Wallman 1854, 1856). Also this taxon was reported from this habitat as Chara vulgaris without author citation (Thomson \& Thomson 1835) and was considered as a synonym of $C$. vulgaris L. var. vulgaris sensu R. D. Wood (Wood \& Imahori 1965) or $C$. globularis Thuill. (Langangen in: Guiry \& Guiry 2011). Braun (1868) considered C. fragilis var. meridionalis as a synonym of $C$. strumosa A. Braun, but Wood assumed $C$. fragilis var. meridionalis as a probable synonym of $C$. vulgaris var. vulgaris f. strumosa (A. Braun) R. D. Wood (=C. strumosa A. Braun; Wood \& Imahori 
1965: 87), but he did not study specimens of Chara fragilis var. meridionalis (Wood \& Imahori 1965: 168). The latter taxon was found also in southern part of Sinai Peninsula (Decaisne 1834) and in Southern Africa at the Cape of Good Hope (Braun 1834; Wood \& Imahori 1965).

Till 1960s, the charophytes of Israel did not get special attention of researchers. Vilhelm (1928) reported Chara gymnophylla A. Braun from the Wâdi el-Kelt between Jericho and Jerusalem collected by Fr. Nabélek (Brno) on the $30^{\text {th }}$ of March 1909. Buxton (1924) reported Chara vulgaris (as C. foetida) from the Wadi Gaza (as Wadi Ghuzze) in recent Gaza strip, abundant Chara sp. in a stream which runs down from Kabatieh and crosses the main road south of Jenin and abundant Chara sp. in pools of Wadi Kabala between Jerusalem and Latrun. These localities were found in 1921-1923. E. M. Blackwell found monospecific communities of Chara in Solomon's ponds near Bethlehem in August 1923 after significant water level decrease (Washbourn \& Jones 1937). Chara connivens Salzm. ex A. Braun was dominant in the lowest pool. Jones (1940) found Chara vulgaris and Nitellopsis obtusa (Desv.) J. Groves in lake Hula (Huleh) and also Nitella oligospira A. Braun (as N. oligospora A. Braun) in the swamp to the north of the Lake Hula. These species were collected before drainage of this wetland in 1950s (Hambright \& Zohary 1998). Rayss (1951) reported Chara connivens, $C$. dissoluta A.Braun ex Leonhardi, C. vulgaris (as C. foetida A. Braun) and Nitella mucronata (A. Braun) Miq. from a single locality each from the present Israeli territory. Also Chara connivens was reported from the Palestine with no mention of exact locality (Groves \& Bullock-Webster 1924; Corillion 1957 cited from: Wood \& Imahori 1965). Chara vulgaris (as C. foetida) was reported from the Palestine as a tool for mosquito larvae control in water bodies of this region in 1920s (Proc. Sixth Meeting Anti-malaria Advisory Commission, Palestine. Nov. 30, 1922 cited in: Barber 1924; Sufian 2007).

Yaakov Lipkin collected extensive herbarium of charophytes since 1967 (http://www.tau.ac.il/lifesci/ botany/USR/lipkin/Herbarium/). More than 700 herbarium sheets of charophytes are stored in the herbarium of the Tel-Aviv University (TELA), but they are not described and have not been published till now. This collection contains Chara, Nitella and Tolypella specimens.

Vernon W. Proctor and Michael C. Grant used living specimens from Israel collected mostly by Y. Lipkin for breeding experiments (Grant 1970; Proctor 1970, 1971a, 1971b, 1975, 1976, 1980; Proctor \& Wiman 1971; Grant \& Proctor 1972). The seven species and lists of several localities were reported in their articles. The voucher specimens were stored in the following

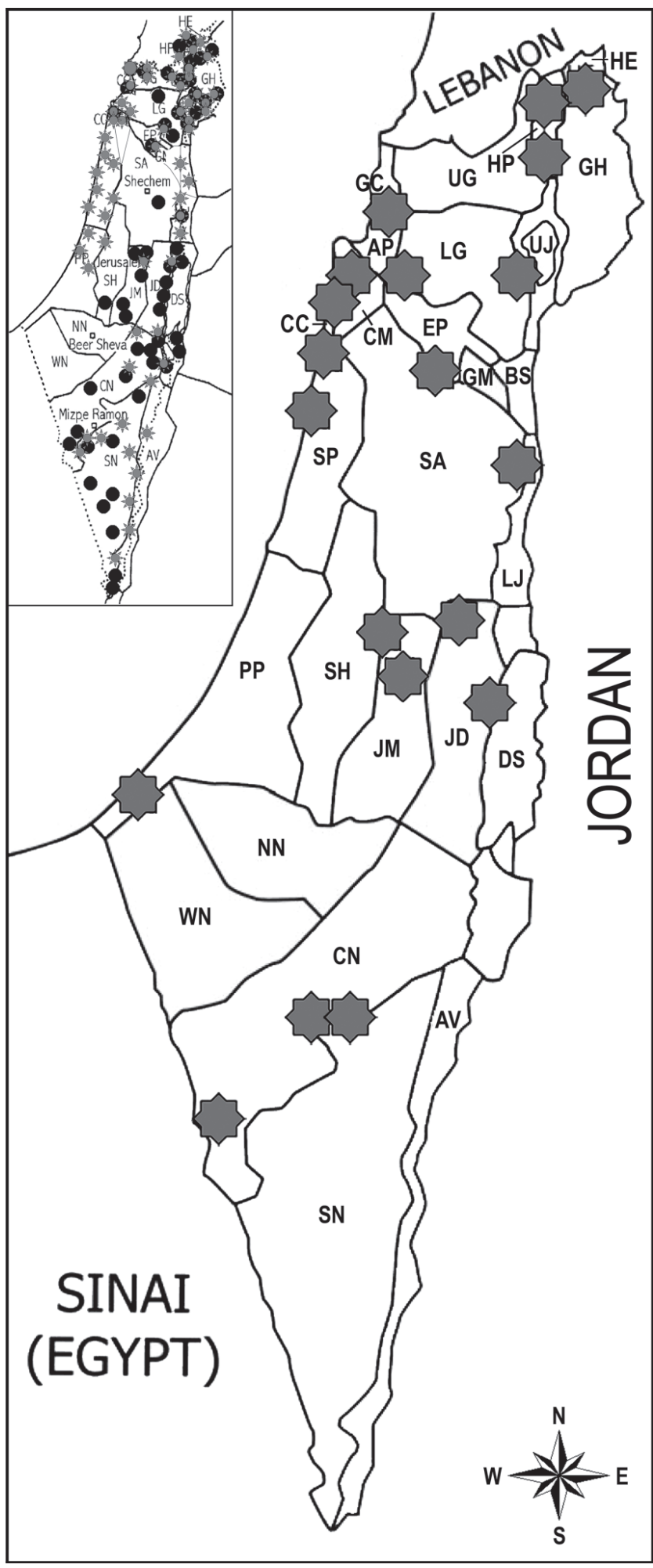

Fig. 2. Map of natural regions (ecoregions) of Israel (after Zohary 1966) showing sampling sites

Explanations: black circles on insertion - sampling sites before our studies, 1878-2000; asterisks - our sampling sites 2001-2011 and all known charophytes localities as grey asterisks. Not all locations are depicted, some of them overlap or it was difficult to mark exact locations from the published data. Northern Israel: AP - Akko Plane; BS - Bet Shean Valley; CC - Carmel Coast; CM - Mount Carmel; EP - Esdraelon Plain; GC Galilee Coast; GH - Golan Heights; GM - Gilboa Mountains; HE - Hermon; HP - Hula Plain; LG - Lower Galilee; UG - Upper Galilee; UJ - Upper Jordan Valley; Central Israel: DS - Dead Sea Area; JD - Judean Desert; JM - Judean Mountains; PP - Philistine Plain; SA - Samaria; SH - Shefela; SP - Sharon Plain; Southern Israel: AV - Arava Valley; CN - Central Negev; LJ - Lower Jordan Valley; NN - Northern Negev; SN - Southern Negev; WN - Western Negev 
Table 1. Historical and recent flora of Israel charophytes

\begin{tabular}{|c|c|c|c|}
\hline & Species and varieties & $\begin{array}{c}\text { Historical } \\
\text { XIX - middle XX }\end{array}$ & $\begin{array}{c}\text { Recent } \\
\text { end } \mathrm{XX}-\mathrm{XXI}\end{array}$ \\
\hline 1 & Chara braunii C.C.Gmel. & + & + \\
\hline 2 & C. dissoluta A. Braun ex Leonh. & + & - \\
\hline 3 & C. connivens Salzm. ex A. Braun & + & + \\
\hline 4 & C. contraria A. Braun & + & + \\
\hline 5 & C. globularis Thuill. & + & + \\
\hline 6 & C. "globularis group" undetermined & + & - \\
\hline 7 & C. gymnophylla A. Braun & + & + \\
\hline 8 & C. "hispida group" undetermined & + & - \\
\hline 9 & C. intermedia A. Braun & - & + \\
\hline 10 & C. vulgaris L. var. vulgaris & + & + \\
\hline 11 & C. vulgaris var. longibracteata (Kütz.) J. Groves et G.R. Bullock-Webster & - & + \\
\hline 12 & C. zeylanica Klein ex Willd. sensu R.D. Wood & + & - \\
\hline 13 & Nitella mucronata (A. Braun) Miq. & + & + \\
\hline 14 & N. oligospira A. Braun & + & - \\
\hline 15 & Nitellopsis obtusa (Desv.) J. Groves & + & - \\
\hline \multirow[t]{2}{*}{16} & Tolypella glomerata (Desv.) Leonh. & - & + \\
\hline & Total: 16 species and varietes & 13 & 10 \\
\hline
\end{tabular}

herbaria: New York Botanical Garden (NY), U.S. National Herbarium (US), Berlin Botanical Garden (B), and Tel Aviv University (TELA). The nucleotide sequence of Chara connivens from Israel specimens was used several times in molecular polymorphism research for comparison with other species of charophytes (McCourt et al. 1999; Meiers et al. 1999; Sakayama et al. 2002, 2009; Kato et al. 2008, 2010).

The data till the middle of the $20^{\text {th }}$ century were historical due to a continuous, severe transformation of the environment by human activity. At the end of the $20^{\text {th }}$ century, only the two species were found. Chara braunii C.C.Gmel. was one of the most abundant species of aquatic macrophytes in the artificial, shallow Agmon Lake (Gutman et al. 2001) created in 1994 (Hambright \& Zohary 1998). Chara globularis Thuill. (as C. fragilis Desv.) was collected from ponds in Mount Carmel National Park (Tsarenko et al. 1997).

\subsection{Species richness, distribution, and number of localities: historical data}

According to published data, 13 species, including two undetermined species of Chara, and nearly 23 exact localities of charophytes were reported from Northern and Central Israel (Table 1), including Israeli controlled territories. Almost all known localities were found before 1970. The several localities of sampling sites for species used in breeding experiments (Chara contraria, $C$. gymnophylla which was reported as $C$. squamosa Desf., C. "hispida group", and C. vulgaris) were not published (Grant 1970; Proctor 1971b, 1975, 1976; Grant \& Proctor 1972). According to published approximate maps of distribution and records from adjacent territories (Hart 1891; Corillion \& Guerlesquin 1971; Corillion 1973), we may assume the presence of several other species (Chara canescens Desv. et Loisel. in Loisel., C. hispida L., C. inconnexa Allen, $C$. tomentosa L.).

\subsection{Species richness, distribution, and number of localities: modern data}

The charophytes were found in 56 samples from 23 localities in 8 river drainage basins from 6 natural districts in years 2001-2011. Twelve of those localities were identified in Northern Israel (Fig. 2): 2 - in Akko Plain, 3 - in the Carmel Mountains, 6 - in the Golan Heights, 1 - in the Upper Jordan Valley, 1 locality in Central Israel - in Lower Jordan valley and 10 localities in Southern Israel - in Central Negev, mostly in the Zin River drainage basin. All of them were new localities of charophytes in Israel. The 25 recent localities of charophytes from the Israeli territory are known, taking into account the recently reported localities of Chara braunii (Gutman et al. 2001) and C. globularis (Tzarenko et al. 1997). The charophytes were collected in January and February, from April to August and in November.

We found seven species and one variety of charophytes (Table 1). There are 15 species and four genera of charophytes known from Israel according to published and our data. One genus - Tolypella, and two species - Chara intermedia A. Braun and Tolypella glomerata (Desv.) Leonh. were found for the first time in Israel. Each species was found in a singly locality. Only a few of our findings of charophytes in Central and Northern Israel, mainly in the Upper Jordan and in the Oren River basin, were published elsewhere including erroneous report of $C$. tenuispina A. Braun (Barinova et al. 2005, 2010, 2011; Barinova \& Nevo 2010).

The very surprising fact is the recent rarity of cosmopolitan common species $C$. globularis. This species 
Table 2. The number of recent localities of Israel charophytes

\begin{tabular}{lcccc}
\hline \multirow{2}{*}{ Species and varieties } & \multicolumn{4}{c}{ Number of localities } \\
\cline { 2 - 5 } Chara braunii C.C.Gmel. & Northern & Central & Southern & Total \\
C. connivens Salzm. ex A. Braun & 1 & - & - & 1 \\
C. contraria A. Braun & 1 & - & - & 1 \\
C. globularis Thuill. & - & - & 7 & 7 \\
C. gymnophylla A. Braun & 1 & - & - & 1 \\
C. intermedia A. Braun & 6 & - & 2 & 8 \\
C. vulgaris L. & 1 & - & - & 1 \\
incl. var. vulgaris & 4 & 1 & 9 & 14 \\
$\quad$ var. longibracteata (Kütz.) J. Groves & $(1)$ & $(1)$ & $(1)$ & $(5)$ \\
$\quad$ et G.R. Bullock-Webster & & - & $(8)$ & $(9)$ \\
Nitella mucronata (A. Braun) Miq. & 1 & - & - & 1 \\
Total & - & - & 1 & 1 \\
\hline
\end{tabular}

was reported for several water bodies in Israel (Proctor 1971a; Tsarenko et al. 1997) but now habitats of the coastal plains were lost under anthropogenic impact. Also, the habitats of three species (Chara connivens, C. vulgaris, and Nitella mucronata) in the Hadera River as well as near the Dead Sea in Ghuweira (Rayss 1951) were destroyed.

The Chara gymnophylla A. Braun is the most frequently encountered species in Northern Israel (Table 2). The Chara vulgaris and C. contraria are the most frequently found species in Southern Israel. These three species are known from the greatest number of habitats.

\subsection{Ecology}

The common habitats of charophytes on Israel's territory are river channels and pools and, in particular, artificial water bodies created during the long history of human activity here. The composition of algal communities and their distribution are under variable climatic impact (Barinova et al. 2011), having a strong gradient on this small territory (Nevo 1995).

The historical data are insufficient for charophyte ecology characterization due to the scarcity of reported information about their habitats. It may be concluded that, as at the present time, the charophytes were found in river channels and also in artificial and natural, and permanent and temporal small water bodies. The valid estimation of changes in species composition, distribution, and frequency of occurrence of charophytes in Israel will be possible only after taxonomical treatment of the collection stored in TELA.

At this moment, we may briefly characterize species ecology by selected environmental variables. The Nitella mucronata was found in a habitat with the greatest amount of nitrate nitrogen among charophyte habitats (Table 3). The Chara intermedia is known from waters with the highest conductivity. The $C$. vulgaris was found in a wide range of conductivity. The Chara contraria and Tolypella glomerata are known from localities with TDS nearly $2 \mathrm{gdm}^{-3}$.

We may suppose that the strong, variable distribution of charophytes in space and time resulted from the absence of large water bodies in this region, strong variability of natural environment and long-term, persistent as well as severe human transformation of the environment in Israel.

\section{Conclusion}

According to our preliminary results, we may conclude that charophytes are rather rare plants in

Table 3. Environmental range of charophytes in Israel according to original data

\begin{tabular}{lccccc}
\hline Species and varieties & $\begin{array}{c}\text { Temperature } \\
{\left[{ }^{\circ} \mathrm{C}\right]}\end{array}$ & $\mathrm{pH}$ & $\begin{array}{c}\text { Conductivity } \\
{[\mathrm{mS} / \mathrm{sm}]}\end{array}$ & \multicolumn{2}{c}{ Total dissolved Nitrate nitrogen } \\
solids $\left[\mathrm{mg} / \mathrm{dm}^{3}\right]$ & {$\left[\mathrm{mg} / \mathrm{dm}^{3}\right]$} \\
\hline Chara connivens Salzm. ex A. Braun & 28.4 & 10.2 & 0.61 & 426 & 1.0 \\
C. contraria A. Braun & $23.0-30.0$ & $7.6-8.7$ & $2.62-4.4$ & $1968->1999$ & $0.0-0.3$ \\
C. gymnophylla A. Braun & $14.8-30.5$ & $7.4-8.7$ & $0.22-4.2$ & $155->577$ & $0.6-4.1$ \\
C. intermedia A. Braun & $19.7-31.8$ & $8.4-8.5$ & $8.04-8.12$ & - & $0.1-0.6$ \\
C. vulgaris L. var. vulgaris & $16.0-32.0$ & $6.7-9.0$ & $0.23-7.9$ & $167->454$ & $0.0-0.3$ \\
C. vulgaris var. longibracteata (Kütz.) & $20.8-25.0$ & $7.6-8.7$ & $0.86-9.17$ & - & $0.0-4.5$ \\
J. Groves et G.R. Bullock-Webster & $15.0-18.7$ & $7.7-7.9$ & $0.52-0.54$ & $366-384$ & $5.3-6.5$ \\
Nitella mucronata (A. Braun) Miq. & - & 7.8 & 2.60 & 1948 & - \\
Tolypella glomerata (Desv.) Leonh. & - & & & - \\
\hline
\end{tabular}


Israel. There are 15 species of charophytes known for this territory, but only 9 species were found at present.

We may expect the presence of other species and existence of other localities. Further research is needed not only in taxonomy and ecology but also in morphological and molecular polymorphism as a possible re- flection of different environmental conditions as well as search of new localities.

Acknowledgements. The authors are grateful to L. V. Zhakova (Zoological Institute of RAS, Saint Petersburg, Russia) for valuable comment. The research was partly supported by Israeli Ministry of Absorption and Israel Taxonomy Initiative.

\section{References}

Adler R., Amiran D. H. K., Eliakim H., Gilead M. H., Hinberger Y., Kadmon N., Kantor M., Shachar A. \& TSAMERET R. 1985. Atlas of Israel - Cartography, Physical and Human Geography. 3rd ed. 160 pp. Survey of Israel, Tel-Aviv; Macmillan Publishing Co, New York; Collier Macmillan, London.

BARber M. A. 1924. The effect of Chara robbinsii on mosquito larval. Publ. Health Rep. 39(13): 611-615.

Barinova S. S., Anissimova O. V., Nevo E. \& Wasser S. P. 2005. Diversity and ecology of phytoplankton and periphyton of the Nahal Oren, Alon Natural Park, Northern Israel. Algol. Stud. 116:169-197.

Barinova S. S. \& Nevo E. 2010. The Upper Jordan River Algal Communities are Evidence of Long-Term Climatic and Anthropogenic Impacts. J. Water Resource and Protection. 2: 507-526.

Barinova S., Petrov A. \& Nevo E. 2011. Comparative analysis of algal biodiversity in the rivers of Israel. Central Europ. J. Biol. 6(2): 246-259.

Barinova S. S., Yehuda G. \& Nevo E. 2010. Comparative analysis of algal communities in the rivers of northern and southern Israel as bearing on ecological consequences of climate change. J. Arid Environments. 74: 765-776.

BAR-OR Y. 2000. Restoration of the rivers in Israel's coastal plain. Water Air \& Soil Poll. 123: 311-321.

Bové N. 1834. Relation abrégée d'un voyage botanique en Egypte, dans les trois Arabies, en Palestine et en Syrie. Ann. Sci. Natur. comprenant la zoologie, la botanique, l'anatomie et la physiologie comparée des deux règnes et l'histoire des corps organisés fossiles. Rédigée pour la zoologie par Audouin et Milne-Edwards; pour la botanique par Ad. Brongniart et Guillemin. Seconde série. Tome premier. Botanique, pp. 72-87, 161-179, 230-239. Crochard, Libraire-Éditeur, Paris.

Braun A. 1834. Esquisse monographique du genre Chara. Ann. Sci. Natur. comprenant la zoologie, la botanique, l'anatomie et la physiologie comparée des deux règnes et l'histoire des corps organisés fossiles. Rédigée pour la zoologie par Audouin et Milne-Edwards; pour la botanique par Ad. Brongniart et Guillemin. Seconde série. Tome premier. Botanique, pp. 349-357. Crochard, Libraire-Éditeur, Paris.

Braun A. 1835. Uebersicht der genauer bekannten CharaArten. Flora oder Allgemeine Botanische Zeitung. 18(1: 4): 49-73.

Braun A. 1868. Die Characeen Afrika's. Monatsbericht der Königlichen Akademie der Wissenschaften vom
December 1867. ss. 781-872. Akademische Büchdruckerei, Berlin.

Buxton P. A. 1924. Applied entomology of Palestine, being a report to the Palestine Government. Bull. Entomolog. Res. 14(3): 289-340.

Cirujano S., Cambra J., Sánchez Castillo P. M., Meco A. \& Flor Arnau N. 2007. Flora ibérica. Algas continentales. Carófitos (Characeae). 132 pp. Real Jardín Botánico, Madrid.

Corillion R. 1973. Aspects généraux de la distribution géographique des Characées Africano-malgaches. Comptes rendus Soc. Biogéogr. 49(431): 64-81.

Corillion R. \& Guerlesquin M. 1971. Notes phytogéographiques sur les Charophycées d'Egypte. Rev. Algologique, n.s. 10: 177-191.

Decaisne M. J. 1834. Énumération des plantes recueillies par M. Bové dans les deux Arabies, la Palestine, la Syrie et l'Égypte. Ann. Sci. Natur. comprenant la zoologie, la botanique, l'anatomie et la physiologie comparée des deux règnes et l'histoire des corps organisés fossiles. Rédigée pour la zoologie par Audouin et Milne-Edwards; pour la botanique par Ad. Brongniart et Guillemin. Seconde série. Tome second. Botanique. pp. 5-18, 239-270. Crochard, LibraireÉditeur, Paris.

Galun M. 1970. The lichens of Israel. $116 \mathrm{pp}$. The Israel Academy of Science and Humanities, Jerusalem.

GoldREICH Y. 2003. The climate of Israel: Observation, Research and Application. 270 pp. Kluwer Academic/ Plenum Publishers, New York.

GRANT M. C. 1970. Reproductive isolation between cytotypes of Chara contraria, Master of Science thesis, Graduate Faculty of Texas Tech University, Lubbock, USA.

Grant M. C. \& Proctor V. W. 1972. Chara vulgaris and Chara contraria: Patterns of reproductive isolation for two cosmopolitan species complexes. Evolution. 26: $267-281$.

Groves J. \& Bullock-Webster G. R. 1924. The British Charophyta. 2. Chareae. VIII, (4), 129 pp., Plates XXIXLV. Ray Society, London.

Gutman M., Kaplan D. \& Gutman R. 2001. Restoration and Conservation of Fauna and Flora in the Re-Flooded Hula Wetland in Northern Israel. Final Report (19972001). LIFE - Third Countries. PROJECT No: LIFE TCY/97/1L/O38. http://www.migal-life.co.il/

Hambright K. D. \& Zohary T. 1998. Lakes Hula and Agmon: destruction and creation of wetland ecosystems in 
northern Israel. Wetlands Ecology and Management 6: 83-89.

Hart H. C. 1891. Some account of the fauna and flora of Sinai, Petra, and Wâdy 'Arabah. pp. [v]-x + 1-255. Alexander P. Watt, London.

Hollerbach M. M. \& Krasavina L. K. 1983 The identification manual of freshwater algae of the USSR. Issue 14. The charophytes - Charophyta. 190 pp. Science, Leningrad.

Jones R. F. 1940. Report of the Percy Sladen expedition to Lake Huleh: a contribution to the study of the fresh waters of Palestine. The plant ecology of the district. J. Ecol. 28(2): 357-376.

Kato S., Sakayama H., Morishima H., Sano S., Oomori Y., Kato N., Ito M., Kasai F., Watanabe M. M. \& Nozaki H. 2010. Morphology and molecular phylogeny of Chara altaica (Charales, Charophyceae), a monoecious species of the section Desvauxia. Cytologia. 75: 211-220.

Kato S., Sakayama H., Sano S., Kasai F., Watanabe M. M., TAnaka J. \& Nozaki H. 2008. Morphological variation and intraspecific phylogeny of the ubiquitous species Chara braunii (Charales, Charophyceae) in Japan. Phycologia. 47(2): 191-202.

Krause W. 1997. Charales (Charophyceae). Süßwasserflora von Mitteleuropa. EtTl H., Gärtner G., Heynig H., \& Mollenhauer D. (eds.). B. 18, 202 pp. Gustav Fischer Verlag, Jena.

KütZING F. T. 1849. Species algarum. pp. [i]-vi + [1]-922. F. A. Brockhaus, Lipsiae.

Langangen A. in: Guiry M. D. \& Guiry G. M. 2011. AlgaeBase. World-wide electronic publication, National University of Ireland, Galway. http://www. algaebase.org; searched on 30 October 2011.

McCourt R. M., Karol K. G., Casanova M. T. \& Feist M. 1999. Monophyly of genera and species of Characeae based on $\mathrm{rbcL}$ sequences, with special references to Australian and European Lychnothamnus barbatus (Characeae: Charophyceae). Austral. J. Bot. 47: 361369.

Meiers S. T., Proctor V. W. \& Chapman R. L. 1999. Phylogeny and biogeography of Chara (Charophyta) inferred from 18S rDNA sequences. Austral. J. Bot. 47: 347-360.

Migula W. 1897. Die Characeen Deutschlands, Oesterreichs und der Schweiz. Unter Berücksichtigung aller Arten Europas. L. Rabenhorst - Kryptogamenflora von Deutschland, Oesterreich und der Schweiz. 2. Aufl. Vol. 5. XIII, (3), 765 pp. Verlag Eduard Kummer, Leipzig.

Nevo E. 1995. Asian, African and European biota meet at "Evolution Canyon", Israel: local tests of global biodiversity and genetic diversity patterns. Proc. Royal Soc. Lond. B 262: 149-155.

Perry A. S.\& Perry R.Y. 1989. Effects in arid regions. In: P. Bourdeau, J. A. Haines, W. Klein \& C. R. Krishna Murti (eds.). Ecotoxycology and Climate with Special Reference to Hot and Cold Climates. SCOPE 38. IPCS JOINT SYMPOSIA 9, pp. 155-193. John Wiley \& Sons LtdP, Chichester-New York-BrisbaneToronto-Singapore.
Proctor V. W. 1970. Taxonomy of Chara braunii: an experimental approach. J. Phycol. 6: 317-321.

Proctor V. W. 1971a. Chara globularis Thuillier $(=C$. fragilis Desvaux): breeding patterns within a cosmopolitan complex. Limnol. and Ocean. 16: 422-436.

Proctor V. W. 1971b. Taxonomic significance of monoecism and dioecism in the genus Chara. Phycologia 10: 299307.

Proctor V. W. 1975. The nature of charophyte species. Phycologia 14: 97-113.

Proctor V. W. 1976. Genetics of Charophyta. In: R. A. LewIN (ed.). The genetics of algae, pp. 210-218. University of California Press, Berkeley-Los Angeles.

Proctor V. W. 1980. Historical biogeography of Chara (Charophyta): an appraisal of the Braun-Wood classification plus a falsifiable alternative for future consideration. J. Phycol. 16: 218-233.

Proctor V. W. \& Wiman F. H. 1971. An experimental approach to the systematics of the monoecious-conjoined members of the genus Chara, series Gymnobasalia. Am. J. Bot. 58: 885-893.

RAYSS T. 1951. Les algues des eaux continentales; materiaux pour la flore algologique de la Palestine. Palest. J. Bot. 5: 71-95.

Sakayama H., Nozaki H., Kasaki H. \& Hara. Y. 2002. Taxonomic re-examination of Nitella (Charales, Charophyceae) from Japan, based on microscopical studies of oospore wall ornamentation and rbcL gene sequences. Phycologia 41: 397-408.

Sakayama H., Kasai F., Nozaki H., Watanabe M. M., Kawachi M., Shigyo M., Nishiniro J., Washitani I., KRIENITZ L. \& ITO M. 2009. Taxonomic reexamination of Chara globularis (Charales, Charophyceae) from Japan based on oospore morphology and rbcL gene sequences, and the description of $C$. leptospora sp. nov. J. Phycol. 45: 917-927.

Schubert H. \& Blindow I. (eds.). 2004. Charophytes of the Baltic Sea. 326 pp. A.R.G. Gantner Verlag, Ruggel.

Sufian S. M. 2007. Healing the land and the nation: malaria and the Zionist project in Palestine, 1920-1947. [vii]-[xx]+1-385 pp. University of Chicago Press, Chicago.

Thomson R. D. \& Thomson T. 1835. V. Plants of Arabia, Palestine and Egypt. In: R. D. Thomson, T. ThOmson Records of general science, vol. II. (No. XI. X. Scientific Intelligence), pp. 398. London, John Taylor (Bookseller and Publisher of University of London).

Tsarenko P. M., Stupina V. V., Mordvintseva G. M., Wasser S. P. \& Nevo E. 1997. Chlorophyta: Checklist of Continental Species from Israel. 150 pp. Peledfus Publishing House, Haifa-Kyiv.

Vilhelm J. 1928. Characeae Europae orientalis et Asiae ex herbario instituti cryptogamici horti botanici reipublicae rossicae (ante Petropolitani). Spisy vydávané Prirodovedeckov Fakultov Karlovy University (Publications de la Faculté des Sciences de l'Université Charles, Praha) 80: 1-24.

WaLlman J. H. 1854. Försök till en systematisk uppställning af växtfamiljen Characea. In: Kongl. Vetenskaps Akademiens Handlingar foer ar 1852, pp. 229-331. P. A. Norstedt \& Söner, Kongl. Boktrydare, Stockholm. 
Wallman J. H. 1856. Essai d'une exposition de la Famille des Characées. Traduit du Suédois par M. le Dr. W. Nylander. Actes de la Société Linnéenne de Bordeaux. 21 (sér. 3, vol. 1): 1-90.

Washbourn R. \& Jones R. F. 1937. Percy Sladen expedition to Lake Huleh, Palestine. Proc. Linn. Soc. London 149(2): 97-99.

WoOd R. D. \& IMAHORI K. 1964. Iconograph of the Characeae. In: R. D. Wood \& K. IMAHORI (eds.). A revision of the
Characeae. Vol. II, v-Xv+icones 1-395+1-7 pp. Cramer, Weinheim.

Wood R. D. \& Imahori K. 1965. Monograph of the Characeae. In: R. D. WoOd \& K. IMAHori (eds.). A revision of the Characeae. Vol. I, xi-[xxiv]+1-904 pp. Cramer, Weinheim.

Zohary M. 1966. Flora Palaestina, Part I - Text. 364 pp. Israel academy of Sciences and Humanities, Jerusalem. 